\title{
Rhythm and conduction disturbances after Tetralogy of Fallot correction
}

\author{
M Chira*, DF Ciotlaus \\ From 23rd World Congress of the World Society of Cardio-Thoracic Surgeons \\ Split, Croatia. 12-15 September 2013
}

\section{Background}

Rhythm and conduction disturbances are not uncommon complication after surgical correction of Tetralogy of Fallot. Arrhythmias after surgical correction of congenital heart defects are extensively studied in international literature, but the results are not similar. This study highlights the higher risk of arrhythmias when the TOF surgical correction is delayed.

\section{Methods}

The study is based on a group of 71 pediatric patients operated in Heart Institute between September, 2001 and July, 2006, surgically corrected per primam, without prior palliations. The surgical techniques were: transannular patch (46), infundibular patch (12), infundibular patch + pulmonary patch (5), transatrial + transpulmonary repair (8). The patients were divided into 2 groups, correction under 1 year of age and correction above 1 year of age, for comparative study of results. From the 71 patients group, 58 were followed up at 43 months interval group 1 , and 48 months interval group 2, by standard electrocardiography, 24 hours Holter monitoring and echocardiography.

\section{Results}

Major differences between the two groups were recorded: the QRS and QTc duration were significantly different between the 2 groups, right bundle branch block with left anterior hemiblock was noticed especially in patients operated over 1 year of age, ventricular arrhythmias were present especially in the same group of patients operated over 1 year and did not appear in patients with transatrial and transpulmonary repair; furthermore ventricular arrhythmias were especially present in patients with postoperative severe pulmonary

\footnotetext{
* Correspondence: chiramanuel@hotmail.com

Cardiovascular Department, Polisano Hospital, Sibiu, Romania
}

regurgitation; the mean QRS duration was intensely significant correlated with the type of arrhythmia.

\section{Conclusions}

Rhythm and conduction disturbances are statistically significant correlated with the age at correction (the greater the age at operation, the bigger the risk for this type of complications), moreover being correlated with the surgical technique, as well.

Published: 11 September 2013

doi:10.1186/1749-8090-8-S1-085

Cite this article as: Chira and Ciotlaus: Rhythm and conduction

disturbances after Tetralogy of Fallot correction. Journal of Cardiothoracic Surgery 2013 8(Suppl 1):085.
Submit your next manuscript to BioMed Central and take full advantage of:

- Convenient online submission

- Thorough peer review

- No space constraints or color figure charges

- Immediate publication on acceptance

- Inclusion in PubMed, CAS, Scopus and Google Scholar

- Research which is freely available for redistribution 